ISSN 2076-393X

www.mdpi.com/journal/vaccines

Review

\title{
Vaccinia Virus LC16m8 $\Delta$ as a Vaccine Vector for Clinical Applications
}

\section{Minoru Kidokoro ${ }^{1, \dagger}$ and Hisatoshi Shida ${ }^{2, \dagger, *}$}

1 Department of Virology III, National Institute of Infectious Diseases, 4-7-1 Gakuen, Musashimurayama-shi, Tokyo 208-0011, Japan; E-Mail: kidokoro@nih.go.jp

2 Institute for Genetic Medicine, Hokkaido University, Kita-15, Nishi-7, Kita-ku, Sapporo 060-0815, Japan

$\dagger$ These authors contributed equally to this work.

* Author to whom correspondence should be addressed; E-Mail: hshida@igm.hokudai.ac.jp; Tel./Fax: +81-11-706-7543.

Received: 3 June 2014; in revised form: 16 September 2014 / Accepted: 28 September 2014 / Published: 17 October 2014

\begin{abstract}
The LC16m8 strain of vaccinia virus, the active ingredient in the Japanese smallpox vaccine, was derived from the Lister/Elstree strain. LC16m8 is replication-competent and has been administered to over 100,000 infants and 3,000 adults with no serious adverse reactions. Despite this outstanding safety profile, the occurrence of spontaneously-generated large plaque-forming virulent $\mathrm{LC} 16 \mathrm{~m} 8$ revertants following passage in cell culture is a major drawback. We identified the gene responsible for the reversion and deleted the gene $(B 5 R)$ from $\mathrm{LC} 16 \mathrm{~m} 8$ to derive $\mathrm{LC} 16 \mathrm{~m} 8 \Delta$. LC16 $8 \Delta$ is non-pathogenic in immunodeficient severe combined immunodeficiency (SCID) mice, genetically-stable and does not reverse to a large-plaque phenotype upon passage in cell culture, even under conditions in which most LC16m8 populations are replaced by revertants. Moreover, LC16m8 is $>500$-fold more effective than the non-replicating vaccinia virus (VV), Modified Vaccinia Ankara (MVA), at inducing murine immune responses against pathogenic VV. LC16m8 the SIV gag gene, also induced anti-Gag $\mathrm{CD}^{+} \mathrm{T}$-cells more efficiently than MVA and another non-replicating VV, Dairen I minute-pock variants (DIs). Moreover, LC16m8 expressing HIV-1 Env in combination with a Sendai virus vector induced the production of anti-Env antibodies and CD8 ${ }^{+}$T-cells. Thus, the safety and efficacy of LC16m8 $\Delta$ mean that it represents an outstanding platform for the development of human vaccine vectors.
\end{abstract}

Keywords: LC16m84; LC16m8; vaccinia virus; reversion; B5R; MVA; DIs; SIV; HIV 


\section{Introduction}

\subsection{First-Generation Smallpox Vaccines}

Smallpox was eradicated worldwide in the 1970s [1,2]. However, serious public health concerns due to the threat of bioterrorism [3] and natural outbreaks of monkeypox [4,5] at the start of the 21st century have highlighted the necessity for a vaccinia virus (VV)-based smallpox vaccine. Existing vaccine stockpiles have not been updated since the 1970s; because these early vaccines are lymph-derived vaccines produced by propagating vaccine viruses in the skin of animals (i.e., first-generation vaccines (Table 1)), they do not meet good manufacturing practice (GMP) standards [6-8]. Therefore, they are at risk for adventitious microbial contamination. Moreover, these vaccines occasionally caused serious adverse effects (e.g., progressive vaccinia, eczema vaccinatum and post-vaccinial encephalitis) due to the pathogenicity of the vaccine viruses used $[9,10]$.

Table 1. Smallpox vaccines and candidate vaccines classified according to generation.

\begin{tabular}{|c|c|c|c|}
\hline Generation & Product & Platform & Parental Strain \\
\hline \multirow{4}{*}{ First-generation } & Lister/Elstree & Lymph-derived & Lister/Elstree \\
\hline & Dryvax & Lymph-derived & $\mathrm{NYCBH}^{\mathrm{a}}$ \\
\hline & Ikeda & Lymph-derived & Ikeda \\
\hline & Dairen I & Lymph-derived & Dairen I \\
\hline \multirow{4}{*}{ Second-generation } & ACAM1000 & Clonal virus grown in MRC- 5 cells & Dryvax \\
\hline & ACAM2000 & Clonal virus grown in Vero cells & ACAM1000 \\
\hline & Elstree-BN & Lister/Elstree lymph-derived virus passaged in $\mathrm{CEF}^{\mathrm{b}}$ & Lister/Elstree \\
\hline & CCSV & NYCBH lymph-derived virus passaged in MRC-5 cells & NYCBH \\
\hline \multirow{3}{*}{ Third-generation } & $\mathrm{LC} 16 \mathrm{~m} 8^{\mathrm{c}}$ & Minute-pock-forming, temperature-sensitive variant virus & Lister/Elstree \\
\hline & IMVAMUNE (MVA ${ }^{\mathrm{d}}$ ) & MVA571 additionally passaged in CEF & MVA571 \\
\hline & DIs $^{\mathrm{e}}$ & Minute-pock-forming variant virus passaged in eggs & Dairen I \\
\hline \multirow[b]{2}{*}{ Fourth-generation } & LC16m8 $8 \Delta$ & Derived from $\mathrm{LC} 16 \mathrm{~m} 8$ by deleting the $B 5 R$ gene & $\mathrm{LC} 16 \mathrm{~m} 8$ \\
\hline & NYVAC & $\begin{array}{l}\text { Attenuated clonal Copenhagen strain generated by deleting } \\
18 \text { non-essential genes }\end{array}$ & Copenhagen \\
\hline
\end{tabular}

${ }^{\mathrm{a}}$ New York City Board of Health; ${ }^{\mathrm{b}}$ chicken embryo fibroblast; ${ }^{\mathrm{c}}$ Lister Clone $16 \mathrm{~m} 8 ;{ }^{\mathrm{d}}$ Modified Vaccinia Ankara;

e Dairen I minute-pock variants.

\subsection{Second-Generation Vaccines}

To address the issues outlined above, much effort has gone into developing safer smallpox vaccine candidates. Some studies aimed to generate vaccines using a sterile cell culture technique to reduce the risk of contamination by adventitious agents (second-generation vaccines) (see Table 1) [11]. For example, ACAM1000 [12,13] was propagated in MRC-5 cells (diploid human lung fibroblasts) using a single clone VV isolated from a Dryvax calf lymph vaccine (manufactured by Wyeth Laboratories using New York City Board of Health (NYCBH)). ACAM2000 was prepared in Vero cells under serum-free conditions using ACAM1000 as the seed virus [13,14]. The cell-cultured smallpox vaccine (CCSV), which was derived from a plaque-purified NYCBH strain, was also prepared in MRC-5 cells [15]. The Elstree-BN vaccine was manufactured in chicken embryo fibroblasts (CEF) using the Lister/Elstree 
(Lister) strain, which was widely used as a lymph-derived vaccine in Europe, Africa and Asia during the global smallpox eradication campaign [16]. The manufacturing of vaccines in cell culture reduced the risk of vaccine contamination by extraneous agents. However, because second-generation vaccines were manufactured using first-generation vaccines or their isolates as seed viruses, their safety profiles were equivalent to those of the original lymph-derived vaccines, i.e., they caused the same adverse events $[13,15]$.

\subsection{Third-Generation Vaccines}

As the global smallpox eradication campaign progressed and the risk of contracting smallpox infections diminished, developed countries began to raise concerns about the side effects associated with lymph-derived smallpox vaccines. This triggered new research to develop alternative attenuated vaccines (third-generation vaccines), such as the Modified Vaccinia Ankara (MVA) [17,18], Dairen I minute-pock variants (DIs) [19] and Lister Clone 16m8 (LC16m8) [20-23]. The main method used to attenuate the VVs was serial passage in primary cell culture or eggs.

MVA was attenuated by serial passage of the chorioallantois VV Ankara strain in CEF (>570 times). This resulted in the loss of approximately $15 \%$ of its genome, including host range-related genes, such as $K 1 L$, and some immunomodulatory genes, thereby generating a phenotype that is unable to replicate in most mammalian cells [24-26]. MVA, which shows an extremely attenuated phenotype in animals and humans [27], was administered to about 120,000 individuals in Western Germany and Turkey during the global eradication campaign with no apparent side effects [28]. Although its ability to protect against smallpox infection was not proven at that time, the need for a smallpox vaccine that was safe for use in immunocompromised individuals (including AIDS patients, patients treated with chemotherapy and transplant recipients) meant that MVA was examined in a number of clinical trials [29-33]. Data from these clinical trials and some animal experiments suggest that although MVA-derived vaccines have an extremely good safety profile; they are less immunogenic than replication-competent VVs, such as Dryvax, LC16m8 and LC16m8 [30,34-36]. For example, data from animal models show that multiple and 1-2 log higher doses of MVA are required to elicit antibody titers comparable with those elicited by replication-competent VVs [34-36].

The DIs strain originates from the Dairen I strain, a smallpox vaccine strain in Japan, and was isolated as a small-sized pock forming variant on chick chorioallantoic membrane (CAM) after 13 passages in one-day-old eggs [19]. As is the case with MVA, DIs harbors a large deletion within the left terminal region of the genome, which contains the host range genes, $K 1 L$ and $C 7 L$, and the immunomodulatory gene, $K 3 L$ [37]; consequently, DIs lacks the ability to replicate in a number of mammalian cell types. Although DIs showed a good safety profile when tested in field trials involving 200 Japanese children, it was not adopted as a smallpox vaccine, because it was less immunogenic than Lister Clone 16 (LC16).

Concerns regarding the side effects of first-generation smallpox vaccines, such as Ikeda, Dairen I and Lister were becoming a problem in Japan during the 1970s. In response to demands for a safer (but still effective) vaccine, the Chiba Serum Institute developed a highly attenuated strain, called LC16m8 [20,23]. LC16m8, which forms minute pocks on the CAM of embryonated eggs, was isolated from the Lister (Lister original, LO) strain via intermediate strains, such as LC16 and its derivative, LC16mO [23,38]. Tests in rabbit and monkey models showed that LC16m8 was markedly less neurovirulent than 
first-generation vaccine strains, such as LO and Dryvax; indeed, its virulence was comparable with that of replication-defective DIs [21-23,39]. Moreover, LC16m8 induced a much weaker dermal reaction in rabbits and humans and showed a lower rate of febrile reactions than $\mathrm{LC} 16 \mathrm{mO}$ (a direct parent of LC16m8) in clinical trials [23,40]. LC16m8 was administrated to approximately 100,000 infants without any serious adverse reactions and proved to be as immunogenic as the parental LO strain $[23,40]$. Therefore, LC16m8 was adopted as the favored vaccine strain in Japan [40].

\subsection{Fourth-Generation Vaccines}

A number of novel attenuation approaches involving direct modification of the VV genome using genetic engineering techniques were used to develop highly attenuated VV strains (fourth-generation vaccines), such as NYVAC and LC16m8 $[6,34,41-46]$. These methods replaced classical attenuation methods based on serial passage in primary cell cultures or eggs. NYVAC was derived from the Copenhagen VV vaccine strain by deleting 18 non-essential genes, which include $C 7 L$ and $K 1 L$, the host range genes; the thymidine kinase gene, a gene related to viral DNA synthesis and the $I 4 L$ gene encoding the large subunit of ribonucleotide reductase. Thus, NYVAC shows very restricted replication in mammalian cells and a highly attenuated phenotype in animals [41]. However, since the replication of NYVAC in non-permissive mammal cells is arrested at an early stage [47] (as is the case for avipoxviruses, such as canary poxvirus and fowl poxvirus), it elicits weaker immune responses than MVA or replication-competent VVs [48].

LC16m $8 \Delta$ should be categorized as a fourth-generation vaccine, because it was obtained from the parental smallpox vaccine strain $(\mathrm{LC} 16 \mathrm{~m} 8)$ by deleting the $B 5 R$ gene, which is responsible for the reversion of LC16m8. Consequently, it shows good genetic stability with very little (if any) reversion; however, it retains its ability to replicate in mammalian cells [34].

\section{2. $\mathrm{LC16} \mathrm{m} 8$ and $B 5 R$}

Takahashi-Nishimaki et al. first identified the VV B5R gene, which is responsible for large-plaque formation and replication in Vero cells, during the course of investigating the mechanism of attenuation to generate LC16m8 [49]. LC16m8 harbors a frameshift mutation due to a single base deletion in the middle of its open reading frame (ORF); this mutation results in the loss of $B 5 R$ function. $B 5 R$ encodes a $42-\mathrm{kDa}$ glycoprotein (B5 protein), which is involved in packaging the intracellular mature virion (IMV) within the trans-Golgi membrane or endosomal cisternae to form an intracellular enveloped virion (IEV) [50-52]. The IEV is transported along microtubules to the cell periphery [53,54], where it adheres to the cell membrane as a cell-associated enveloped virion (CEV). The B5 protein, in cooperation with the A36 and A33 proteins, also participates in the Src kinase-dependent formation of actin-containing microvilli and the subsequent release of the CEV from the cell surface to form an extracellular enveloped virion (EEV) [55,56]. Despite the relative paucity of whole progeny virions, EEVs play an important role in dissemination within the host [57]. Since anti-B5 antibodies neutralize EEV, B5R-expressing VV has been proposed as an effective smallpox vaccine [50,58-61].

When generating and performing basic research on LC16m8, we found that the vaccine spontaneously reverted to large-plaque-forming clones (LPCs) [34]. Thus, we were concerned that LPC contamination might ruin the safety profile of a future $\mathrm{LC} 16 \mathrm{~m} 8$ vaccine. Therefore, we investigated the 
molecular mechanism(s) underlying the reversion, with a focus on the $B 5 R$ gene associated with the formation of large plaques [49].

We isolated three LPC clones from a vaccine stock of LC16m8 and examined their phenotypes in terms of plaque size, dermal reactions in rabbits and pathogenicity in severe combined immunodeficiency (SCID) mice; these phenotypes were compared with those of LC16m8 and the parental virus LC16mO, which retains a fully-functional B5R gene. All three LPC viruses showed phenotypes similar to that of $\mathrm{LC} 16 \mathrm{mO}$, resulting in better growth in cell culture and greater virulence in SCID mice than LC16m8 [34]. As expected, sequencing the $B 5 R$ in these LPCs revealed that the $B 5 R$ ORF contained a single base insertion upstream of the nucleotide that was deleted from the LC16m8 $B 5 R$. It is noteworthy that the nucleotide insertion site in the LPC B5R ORF was different in each of the three clones, even though they originated from the same viral stock, which was prepared through only seven passages after the $\mathrm{LC} 16 \mathrm{~m} 8$ cloning. These results strongly suggest that the reversion of $\mathrm{LC} 16 \mathrm{~m} 8$ is a multi-clonal event and may occur frequently.

\section{LC16m8A}

\subsection{Safety Profile}

To prevent the generation of LC16m8 revertants, we decided to delete the entire $B 5 R$ gene from the LC16m8 genome by homologous recombination to yield LC16m8 [34]. The phenotype of LC16m8 (plaque size and dermal reaction in rabbits) was similar to that of LC16m8. Intraperitoneal (i.p.) injection of $10^{7} \mathrm{PFU}$ of LC16m8 (a dose three logs higher than that needed to elicit protective immunity in $\mathrm{BALB} / \mathrm{c}$ mice) did not cause any symptoms in SCID mice over an eight-week period (Figure 1). MVA and plaque-purified LC16m8 (which contains a very low level of revertants) were also nonpathogenic; however, $\mathrm{LC} 16 \mathrm{mO}$ and $\mathrm{m} 8 B 5 R$ (a derivative constructed by reintroducing the intact $B 5 R$ gene into LC16m8) caused severe rashes and death in SCID mice, even when administered at a dose two $\operatorname{logs}$ lower than LC16m8 (Figure 1).

Figure 1. Pathogenicity of $B 5 R$-defective viruses in severe combined immunodeficiency (SCID) mice. Figure modified from Kidokoro et al. [34].

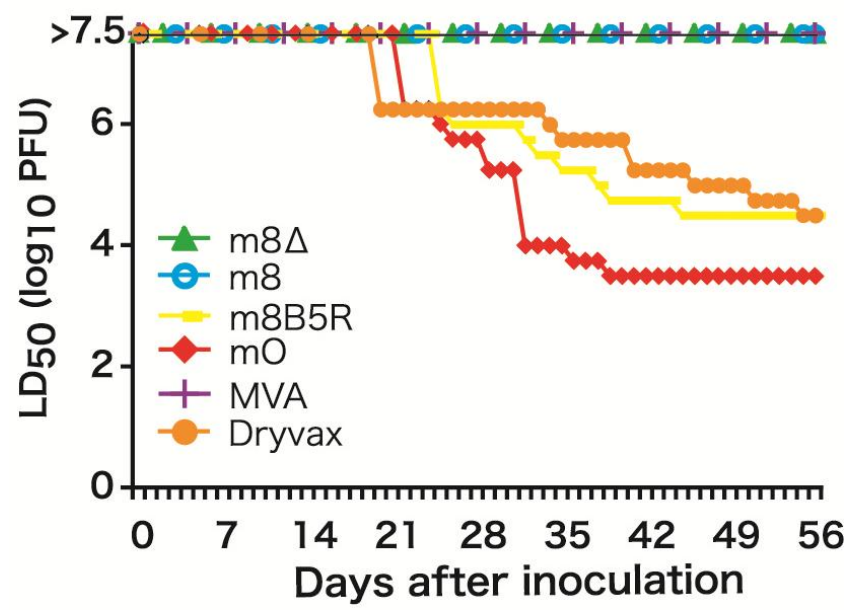


The genetic stability of $\mathrm{LC} 16 \mathrm{~m} 8 \Delta$ was evaluated by serial passage in primary rabbit kidney (PRK) cells, which were used to generate the LC16m8 vaccine. No detectable LPCs emerged from LC16m8 $\Delta$ under any of the test conditions, including those used in vaccine production (passage in PRK cells at $30{ }^{\circ} \mathrm{C}$ ). By contrast, LPCs emerged from LC16 8 that was plaque-purified immediately before testing (Figure 2). It should be noted that once LPCs appeared in the cultures, the LPCs:LC16m8 ratio increased rapidly with the passage number (Figure 2).

Figure 2. Genetic stability of $\mathrm{LC} 16 \mathrm{~m} 8 \Delta$ and $\mathrm{LC} 16 \mathrm{~m} 8$ upon serial passage in primary rabbit kidney cells at different temperatures $\left(30{ }^{\circ} \mathrm{C}\right.$ or $\left.34{ }^{\circ} \mathrm{C}\right)$. Figure modified from Kidokoro et al. [34]. LPC, large-plaque-forming clone.

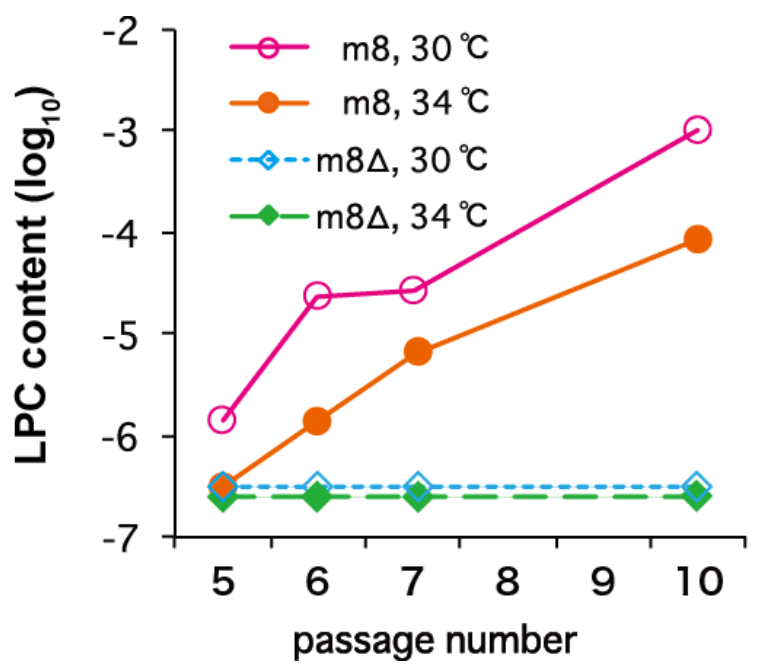

\subsection{Immunogenicity}

The protective immune response elicited by LC16m8 was compared with that elicited by Dryvax, MVA, LC16m8 and LC16m8 derivatives (m8B5R and m8dTM, both of which express the B5 ectodomain at high levels) in a mouse model. This model, in which the immunized mice are challenged with a highly pathogenic VV (the Western Reserve (WR) strain), is one of the most popular methods of evaluating the efficacy of smallpox vaccines [62] (Figure 3). We immunized each group of mice with a single dose $\left(10^{4}, 10^{5}\right.$ or $\left.10^{6} \mathrm{PFU}\right)$ of each VV via the intramuscular (i.m.) route. We found that the level of protective immunity elicited by LCm $8 \Delta$ was comparable with that elicited by Dryvax and superior to that elicited by MVA. For example, the minimal dose $\left(10^{4} \mathrm{PFU}\right)$ of LC16m8 8 or Dryvax fully protected mice from lethal infection with WR, whereas mice immunized with MVA, LC16m8, m8B5R or m8dTM, lost weight and, in some cases, died. The maximum dose $\left(10^{6} \mathrm{PFU}\right)$ of MVA resulted in prominent weight loss after WR challenge. It is noteworthy that immunization with LCm8 $\triangle$ was more efficient than that with $\mathrm{m} 8 B 5 R$ or $\mathrm{m} 8 \mathrm{dTM}$ when compared at their minimal dose. In particular, m8B5R was significantly inferior to LC $16 \mathrm{~m} 8 \Delta$ ( $t$-test, $p=0.005$ ). These results suggest that $B 5 R$ does not play a major role in eliciting protective immune responses in these mice. In addition, LC16m8 $\Delta$ elicited protective immune responses in cynomolgus monkeys and fully protected them against lethal infection with monkeypox virus [63]. Taken together, these data suggest that LC16m8 $\Delta$ is as effective as the first-generation smallpox vaccine, Dryvax. Although several studies report that the B5 protein is the major target of EEV-neutralizing antibodies, which are significant for protection against smallpox 
infection, immunization with B5-deficient vaccine viruses protects animals against lethal challenge by pathogenic orthopoxviruses [58,64-67]. In addition, some reports show that smallpox vaccines do not always induce anti-B5 antibodies, and antibody response profiles against each viral protein are highly heterologous in humans [68-70]. They also concluded that the key to inducing a strong neutralizing antibody response is to elicit antibodies that recognize multiple viral proteins; these antibodies then act synergistically to provide better protection.

Figure 3. (A) Protective immune responses induced by $m 8 \Delta$ and derivative viruses in mice. (A-F) Average body weight of mice immunized (intramuscularly) with $\left(10^{4}-10^{6} \mathrm{PFU}\right)$ vaccinia viruses (VVs) and then challenged intranasally with the Western Reserve (WR) strain. Crosses denote mice that either died or were sacrificed because they lost $>30 \%$ of their body weight. Figure modified from Kidokoro et al. [34].
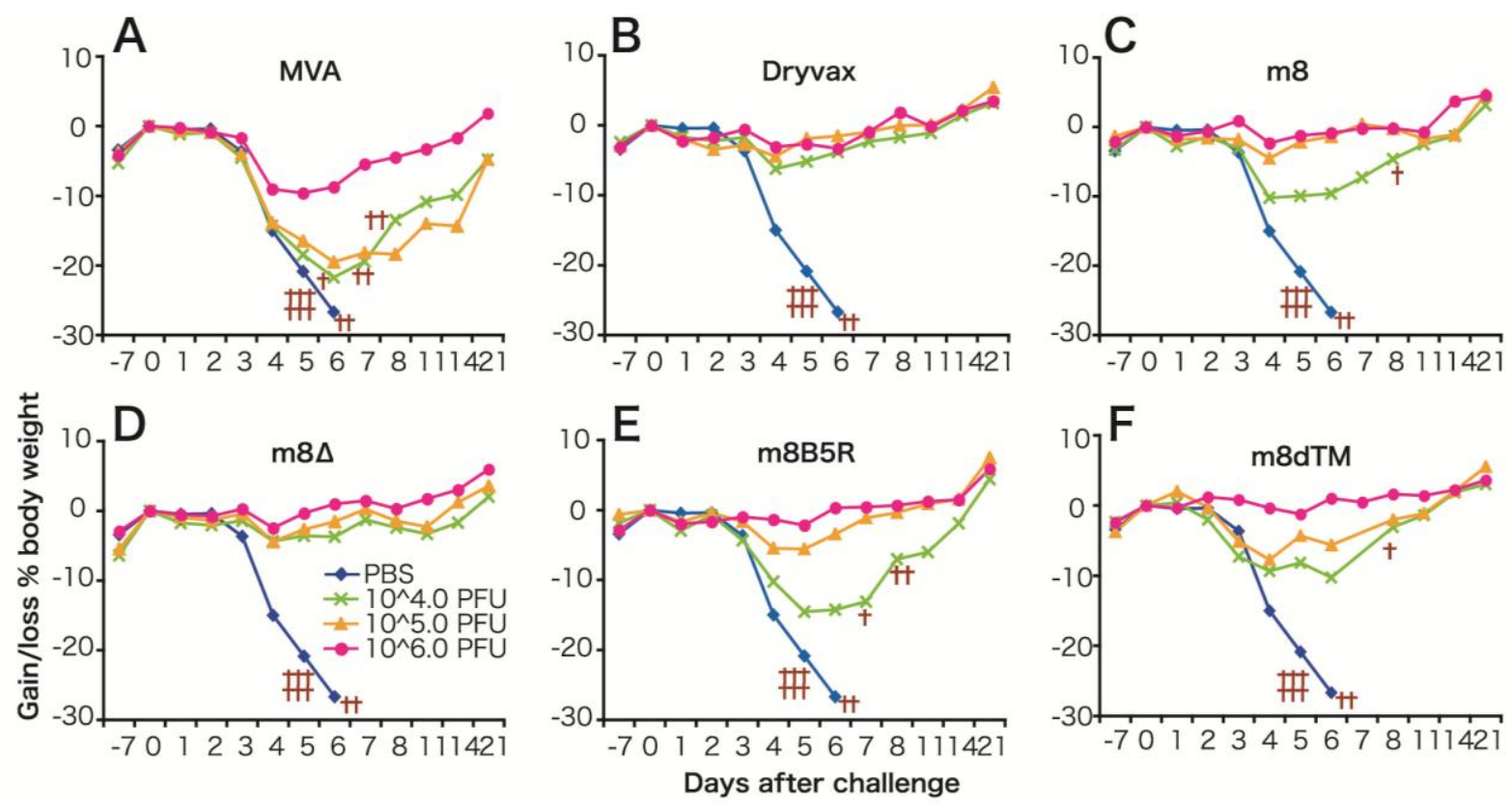

\section{4. $\mathrm{LC16m8} \Delta$ as a Vehicle for Expressing Foreign Genes}

VV has been widely used as a vector for expressing foreign genes, because it has many excellent properties: high expression efficiency, a broad host range, a very large capacity for accepting foreign genes, heat stability and inexpensive vaccine production [71]. Therefore, VV vectors have been examined for use as live vaccines against both human and veterinary infectious diseases and cancers [6-8]. However, concerns about the safety profile of VVs are a major barrier to developing recombinant VV vaccines for use in humans [72].

Most research has focused on replication-defective poxvirus vectors (which have better safety profiles) as vehicles for delivering antigens derived from human pathogens. For example avipox- [73], MVA- and NYVAC-based vectors expressing components of human pathogens, such as HIV-1 and tuberculosis, have been developed and evaluated in monkeys [74,75] and humans [76-79]. However, although promising in animal models, these vaccines did not induce sufficiently strong immune responses in humans, nor did they protect humans from infection $[79,80]$. Therefore, more effective vehicles are needed for human vaccine development. 
Thus, a replication-competent $\mathrm{VV}$ that has been proven to be safe for human vaccination against smallpox could be a good candidate. The safety profile and strong antigenicity of LC16m8 a genetically-stable variant of $\mathrm{LC} 16 \mathrm{~m} 8$, make it a promising vehicle for a vaccine against HIV or other human diseases.

One concern regarding the use of viral vectors is pre-existing immunity against the vector virus, which has the potential to dampen specific immune responses. However, Kohara et al. showed that a recombinant LC16m8 vaccine expressing the SARS coronavirus (SARS-CoV) spike protein elicited neutralizing antibodies against SARS-CoV in rabbits that generated a high titer of anti-LC16m8 antibodies [81]. Another report shows that the VV lacking the B5 ectodomain induces a more potent immune response in vaccinia-immune animals than its wild-type counterpart [82]. These results suggest that $\mathrm{LC} 16 \mathrm{~m} 8 \Delta$ would make a good vector virus for eliciting effective immune responses against foreign antigens in individuals pre-immunized with smallpox vaccines.

Previously, we developed the pSFJ1-10 promoter, an A-type inclusion body (ATI) complex promoter that comprises ten repeat units of the mutated early region of the p7.5 promoter plus the ATI late promoter [83]. This complex promoter possesses strong activity in both the early and late phases of the $\mathrm{VV}$ infection cycle. Indeed, the $\mathrm{H}$ protein of the measles virus and chloramphenicol acetyltransferase, the synthesis of which is driven by this promoter, comprised approximately $10 \%$ of total cellular protein [84,85]. Moreover, we constructed LC16m8 8 VNC110, a vector that harbors pSFJ1-10 along with a multiple cloning site within the hemagglutinin (HA) gene, which can be used for the rapid production of recombinant $\mathrm{LC} 16 \mathrm{~m} 8 \Delta$ through in vitro ligation of the LC16m8 $\mathrm{VNC} 110$ genome with foreign DNA [86]. The foreign genes inserted were stably maintained in the LC16m8 $\Delta$ recombinants constructed by this technique and harboring the p7.5 promoter after several passages in the RK13 cells, a standard cell line for the propagation of VVs.

Using this technique, we tested whether $\mathrm{LC} 16 \mathrm{~m} 8 \Delta$ is a better vector than non-replicating vaccinia virus for the expression of SIV Gag. The Gag proteins of HIV-1 and SIV are major antigens that elicit cytotoxic T lymphocyte (CTL) responses. The activity of anti-Gag CTL inversely correlates with the viral load in HIV-1-infected individuals [87]. Experimental infection of monkeys with SIV suggests that the strength of the anti-Gag CTL response correlates with the containment of SIV [88]. A m8 $\Delta / \mathrm{pSFJ} / \mathrm{SIVGag}$ vector expressing the SIV Gag antigen under control of the pSFJ1-10 promoter generated significantly more Gag protein in vitro and elicited the production of anti-Gag IFN- $\gamma^{+}$T-cells in mice, more efficiently than the non-replicating VV DIs strain (which harbors the gag gene under the control of the same promoter) [86]. The DIs strain is immunogenically similar to MVA [89].

We further optimized LC16m8 for use as a vector by comparing the immunogenicity of SIV Gag proteins expressed under the control of either the pSFJ1-10 promoter or the p7.5 promoter, which is a classical early-late promoter [90] with moderate activity (although weaker than that of pSFJ1-10). Preliminarily observations indicated that expressing too much foreign protein led to a reduction in VV propagation in vitro; therefore, the balance between the expression of a foreign antigen and viral propagation in vivo might be crucial for optimal immunogenicity. Thus, we compared the immunogenicity and virulence of $\mathrm{m} 8 \Delta / \mathrm{p} 7.5 / \mathrm{SIVGag}$ with that of $\mathrm{m} 8 \Delta / \mathrm{pSFJ} / \mathrm{SIVGag}$ in the setting of a recombinant Bacillus Calmette-Guerin (BCG) prime/recombinant $\mathrm{LC} 16 \mathrm{~m} 8 \Delta$ boost vaccination protocol. This setting was based on the observation that long-term maintenance of effector memory T-cells (Tem) with the capacity to immediately attack SIV-infected cells restricts infection by antibody-resistant SIV at the site 
of virus entry. This was achieved using vaccine approaches that persistently express viral antigens in vaccinated macaques via the use of a cytomegalovirus (CMV) vector, thereby resulting in continuous immune stimulation [91,92]. Since BCG persists in vaccinated individuals for long periods of time (up to 10 years) without serious symptoms, vaccination with BCG expressing the Gag protein may be expected to induce Gag-specific $\mathrm{CD} 8^{+} \mathrm{T}$-cells and to maintain immunological memory (via Tem) for a long time. Vaccination studies in mice revealed that $\mathrm{m} 8 \Delta / \mathrm{pSFJ} / \mathrm{SIVGag}$ was less pathogenic and elicited Gag-specific IFN- $\gamma^{+}, \mathrm{CD} 107 \alpha^{+}$and $\mathrm{CD}^{+}$T-cells more efficiently than $\mathrm{m} 8 \Delta / \mathrm{p} 7.5 / \mathrm{SIVGag}$. Tem were detected even at four months after boosting with $\mathrm{m} 8 \Delta / \mathrm{pSFJ} / \mathrm{SIVGag}$. Therefore, LC16m8 $\Delta$ that express SIV Gag under the control of the pSFJ1-10 promoter induced more efficient and long-lasting immune responses than $\mathrm{LC} 16 \mathrm{~m} 8 \Delta$ harboring the $\mathrm{p} 7.5$ promoter [93].

Although inducing both anti-HIV-1 antibody and cytotoxic $\mathrm{CD}^{+}$T-cells is an effective way of preventing HIV-1 infection, it is often difficult to induce the production of anti-HIV-1 antibodies, particularly neutralizing antibodies, at a high titer. For example, only a low titer of anti-HIV-1 Env antibodies was observed, even after repeated immunization with an MVA-based vector [94]. Repetitive antigenic stimulation is required for affinity maturation, the process by which high avidity neutralizing antibodies against HIV-1 are generated. Long-lasting expression of antigen by a replication-competent vector, such as $\mathrm{LC} 16 \mathrm{~m} 8 \Delta$, may enable repeated immunological presentation, which induces affinity maturation.

We next examined the ability of LC16m8 8 expressing the HIV-1 Env gene to elicit anti-HIV-1 antibodies and $\mathrm{CD}^{+} \mathrm{T}$-cells in mice in the setting of a recombinant $\mathrm{LC} 16 \mathrm{~m} 8 \Delta$ prime followed by a Sendai virus vector boost. We found that this vaccination regimen led to the efficient induction of both Env-specific CD8 ${ }^{+}$T-cells and anti-Env antibodies, including neutralizing antibodies. These results are in sharp contrast to those reported by studies that used vaccine regimens based on priming with an Env-expressing plasmid followed by a boost with the LC16m8 8 or SeV vector; such an approach mainly induced cell-mediated immune responses [95].

\section{Conclusions}

Despite its replication-competent phenotype, $\mathrm{LC} 16 \mathrm{~m} 8 \Delta$ is highly attenuated and shows no pathogenic effects in SCID mice (similar to replication-defective VVs, such as MVA). However, it is a comparably effective smallpox vaccine with respect to Dryvax. Moreover, LC16m8 $\Delta$-based vectors induce both antibody- and cell-mediated immune responses against foreign antigens more efficiently than non-replicating VV vectors. Therefore, LC16 $8 \Delta$ is superior to non-replicating VV vectors and is suitable for use in humans. We also point out that $\mathrm{LC} 16 \mathrm{~m} 8 \Delta$ recombinants may be useful as a dual vaccine against both smallpox and pathogens targeted with the inserted genes.

\section{Acknowledgments}

We thank Hanako Yoshizawa and Kazuyoshi Suzuki for providing background information regarding the development of LC16m8. 


\section{Author Contributions}

Both authors contributed equally to this work.

\section{Conflicts of Interest}

The authors declare no conflict of interest.

\section{References}

1. Fenner, F.; Henderson, D.A.; Arita, I.; Jezek, Z.; Ladnyi, I.D.; Organization, W.H. Smallpox and Its Eradication; World Health Organization: Geneva, Switzerland, 1988.

2. Wehrle, P.F. A reality in our time - Certification of the global eradication of smallpox. J. Infect. Dis. 1980, 142, 636-638.

3. Henderson, D.A.; Inglesby, T.V.; Bartlett, J.G.; Ascher, M.S.; Eitzen, E.; Jahrling, P.B.; Hauer, J.; Layton, M.; McDade, J.; Osterholm, M.T.; et al. Smallpox as a biological weapon: Medical and public health management. Working group on civilian biodefense. JAMA 1999, 281, 2127-2137.

4. Reed, K.D.; Melski, J.W.; Graham, M.B.; Regnery, R.L.; Sotir, M.J.; Wegner, M.V.; Kazmierczak, J.J.; Stratman, E.J.; Li, Y.; Fairley, J.A.; et al. The detection of monkeypox in humans in the western hemisphere. N. Engl. J. Med. 2004, 350, 342-350.

5. The Centers for Disease Control and Prevention. Multistate outbreak of monkeypox-Illinois, indiana, and wisconsin, 2003. JAMA 2003, 290, 30-31.

6. Jacobs, B.L.; Langland, J.O.; Kibler, K.V.; Denzler, K.L.; White, S.D.; Holechek, S.A.; Wong, S.; Huynh, T.; Baskin, C.R. Vaccinia virus vaccines: Past, present and future. Antivir. Res. 2009, 84, $1-13$.

7. Walsh, S.R.; Dolin, R. Vaccinia viruses: Vaccines against smallpox and vectors against infectious diseases and tumors. Expert Rev. Vaccines 2011, 10, 1221-1240.

8. Verardi, P.H.; Titong, A.; Hagen, C.J. A vaccinia virus renaissance: New vaccine and immunotherapeutic uses after smallpox eradication. Human Vaccines Immunother. 2012, 8, 961-970.

9. Casey, C.G.; Iskander, J.K.; Roper, M.H.; Mast, E.E.; Wen, X.J.; Torok, T.J.; Chapman, L.E.; Swerdlow, D.L.; Morgan, J.; Heffelfinger, J.D.; et al. Adverse events associated with smallpox vaccination in the United States, January-October 2003. JAMA 2005, 294, 2734-2743.

10. Sejvar, J.J.; Labutta, R.J.; Chapman, L.E.; Grabenstein, J.D.; Iskander, J.; Lane, J.M. Neurologic adverse events associated with smallpox vaccination in the united states, 2002-2004. JAMA 2005, 294, 2744-2750.

11. Murphy, F.A.; Osburn, B.I. Adventitious agents and smallpox vaccine in strategic national stockpile. Emerg. Infect. Dis. 2005, 11, 1086-1089.

12. Weltzin, R.; Liu, J.; Pugachev, K.V.; Myers, G.A.; Coughlin, B.; Blum, P.S.; Nichols, R.; Johnson, C.; Cruz, J.; Kennedy, J.S.; et al. Clonal vaccinia virus grown in cell culture as a new smallpox vaccine. Nat. Med. 2003, 9, 1125-1130.

13. Frey, S.E.; Newman, F.K.; Kennedy, J.S.; Ennis, F.; Abate, G.; Hoft, D.F.; Monath, T.P. Comparison of the safety and immunogenicity of ACAM1000, ACAM2000 and Dryvax ${ }^{\circledR}$ in healthy vaccinia-naive adults. Vaccine 2009, 27, 1637-1644. 
14. Monath, T.P.; Caldwell, J.R.; Mundt, W.; Fusco, J.; Johnson, C.S.; Buller, M.; Liu, J.; Gardner, B.; Downing, G.; Blum, P.S.; et al. Acam 2000 clonal vero cell culture vaccinia virus (New York city board of health strain)-A second-generation smallpox vaccine for biological defense. Int. J. Infect. Dis. 2004, 8, 31-44.

15. Greenberg, R.N.; Kennedy, J.S.; Clanton, D.J.; Plummer, E.A.; Hague, L.; Cruz, J.; Ennis, F.A.; Blackwelder, W.C.; Hopkins, R.J. Safety and immunogenicity of new cell-cultured smallpox vaccine compared with calf-lymph derived vaccine: A blind, single-centre, randomised controlled trial. Lancet 2005, 365, 398-409.

16. Stittelaar, K.J.; van Amerongen, G.; Kondova, I.; Kuiken, T.; van Lavieren, R.F.; Pistoor, F.H.; Niesters, H.G.; van Doornum, G.; van der Zeijst, B.A.; Mateo, L.; et al. Modified vaccinia virus ankara protects macaques against respiratory challenge with monkeypox virus. J. Virol. 2005, 79, 7845-7851.

17. Stickl, H.; Hochstein-Mintzel, V.; Mayr, A.; Huber, H.C.; Schafer, H.; Holzner, A. MVA vaccination against smallpox: Clinical tests with an attenuated live vaccinia virus strain (MVA) (in German). Dtsch. Med. Wochenschr. 1974, 99, 2386-2392.

18. Mayr, A.; Stickl, H.; Muller, H.K.; Danner, K.; Singer, H. The smallpox vaccination strain MVA: Marker, genetic structure, experience gained with the parenteral vaccination and behavior in Organisms with a debilitated defence mechanism (in German). Zentralbl. Bakteriol. B 1978, 167, 375-390.

19. Kitamura, T.; Kitamura, Y.; Tagaya, I. Immunogenicity of an attenuated strain of vaccinia virus on rabbits and monkeys. Nature 1967, 215, 1187-1188.

20. Hashizume, S. Special edition future of smallpox vaccination: Everything about attenuated smallpox vaccines. Basics of new attenuated smallpox vaccine strain LC16m8. Rinshotouirusu 1975, 3, 229-235.

21. Morita, M.; Aoyama, Y.; Arita, M.; Amona, H.; Yoshizawa, H.; Hashizume, S.; Komatsu, T.; Tagaya, I. Comparative studies of several vaccinia virus strains by intrathalamic inoculation into cynomolgus monkeys. Arch. Virol. 1977, 53, 197-208.

22. Morita, M.; Arita, M.; Komatsu, T.; Amano, H.; Hashizume, S. A comparison of neurovirulence of vaccinia virus by intrathalamic and/or intracisternal inoculations into cynomolgus monkeys. Microbiol. Immunol. 1977, 21, 417-418.

23. Hashizume, S.; Yoshizawa, H.; Morita, M.; Suzuki, K. Properties of Attenuated Mutant of Vaccinia Virus, LC16m8, Derived from Lister Strain; Elsevier Science Publishing Co. Inc.: New York, NY, USA, 1985.

24. Meyer, H.; Sutter, G.; Mayr, A. Mapping of deletions in the genome of the highly attenuated vaccinia virus MVA and their influence on virulence. J. Gen. Virol. 1991, 72, 1031-1038.

25. Wyatt, L.S.; Carroll, M.W.; Czerny, C.P.; Merchlinsky, M.; Sisler, J.R.; Moss, B. Marker rescue of the host range restriction defects of modified vaccinia virus Ankara. Virology 1998, 251, 334-342.

26. Perkus, M.E.; Goebel, S.J.; Davis, S.W.; Johnson, G.P.; Limbach, K.; Norton, E.K.; Paoletti, E. Vaccinia virus host range genes. Virology 1990, 179, 276-286. 
27. Hochstein-Mintzel, V.; Hanichen, T.; Huber, H.C.; Stickl, H. An attenuated strain of vaccinia virus (MVA). Successful intramuscular immunization against vaccinia and variola (in German). Zentralbl. Bakteriol. Orig. A 1975, 230, 283-297.

28. Mayr, A. Smallpox vaccination and bioterrorism with pox viruses. Comp. Immunol. Microbiol. Infect. Dis. 2003, 26, 423-430.

29. Vollmar, J.; Arndtz, N.; Eckl, K.M.; Thomsen, T.; Petzold, B.; Mateo, L.; Schlereth, B.; Handley, A.; King, L.; Hulsemann, V.; et al. Safety and immunogenicity of imvamune, a promising candidate as a third generation smallpox vaccine. Vaccine 2006, 24, 2065-2070.

30. Frey, S.E.; Newman, F.K.; Kennedy, J.S.; Sobek, V.; Ennis, F.A.; Hill, H.; Yan, L.K.; Chaplin, P.; Vollmar, J.; Chaitman, B.R.; et al. Clinical and immunologic responses to multiple doses of imvamune (modified vaccinia Ankara) followed by dryvax challenge. Vaccine 2007, 25, 8562-8573.

31. Kennedy, J.S.; Greenberg, R.N. Imvamune: Modified vaccinia Ankara strain as an attenuated smallpox vaccine. Expert Rev. Vaccines 2009, 8, 13-24.

32. Seaman, M.S.; Wilck, M.B.; Baden, L.R.; Walsh, S.R.; Grandpre, L.E.; Devoy, C.; Giri, A.; Noble, L.C.; Kleinjan, J.A.; Stevenson, K.E.; et al. Effect of vaccination with modified vaccinia Ankara (ACAM3000) on subsequent challenge with Dryvax. J. Infect. Dis. 2010, 201, 1353-1360.

33. Wilck, M.B.; Seaman, M.S.; Baden, L.R.; Walsh, S.R.; Grandpre, L.E.; Devoy, C.; Giri, A.; Kleinjan, J.A.; Noble, L.C.; Stevenson, K.E.; et al. Safety and immunogenicity of modified vaccinia Ankara (ACAM3000): Effect of dose and route of administration. J. Infect. Dis. 2010, 201, 1361-1370.

34. Kidokoro, M.; Tashiro, M.; Shida, H. Genetically stable and fully effective smallpox vaccine strain constructed from highly attenuated vaccinia LC16m8. Proc. Natl. Acad. Sci. USA 2005, 102, 4152-4157.

35. Meseda, C.A.; Garcia, A.D.; Kumar, A.; Mayer, A.E.; Manischewitz, J.; King, L.R.; Golding, H.; Merchlinsky, M.; Weir, J.P. Enhanced immunogenicity and protective effect conferred by vaccination with combinations of modified vaccinia virus Ankara and licensed smallpox vaccine dryvax in a mouse model. Virology 2005, 339, 164-175.

36. Wyatt, L.S.; Earl, P.L.; Eller, L.A.; Moss, B. Highly attenuated smallpox vaccine protects mice with and without immune deficiencies against pathogenic vaccinia virus challenge. Proc. Natl. Acad. Sci. USA 2004, 101, 4590-4595.

37. Ishii, K.; Ueda, Y.; Matsuo, K.; Matsuura, Y.; Kitamura, T.; Kato, K.; Izumi, Y.; Someya, K.; Ohsu, T.; Honda, M.; et al. Structural analysis of vaccinia virus Dis strain: Application as a new replication-deficient viral vector. Virology 2002, 302, 433-444.

38. Kenner, J.; Cameron, F.; Empig, C.; Jobes, D.V.; Gurwith, M. LC16m8: An attenuated smallpox vaccine. Vaccine 2006, 24, 7009-7022.

39. Kempe, C.H.; Fulginiti, V.; Minamitani, M.; Shinefield, H. Smallpox vaccination of eczema patients with a strain of attenuated live vaccinia (CVI-78). Pediatrics 1968, 42, 980-985.

40. Yamaguchi, M.; Kimura, M.; Hirayama, M. Vaccination research groups research report: Ministry of health and welfare special research: Postvaccination side effects and research regarding treatment of complications (in Japanese). Rinsho Uirusu Clin. Virus 1975, 3, 225-228. 
41. Tartaglia, J.; Perkus, M.E.; Taylor, J.; Norton, E.K.; Audonnet, J.C.; Cox, W.I.; Davis, S.W.; van der Hoeven, J.; Meignier, B.; Riviere, M.; et al. NYVAC: A highly attenuated strain of vaccinia virus. Virology 1992, 188, 217-232.

42. Paoletti, E.; Tartaglia, J.; Taylor, J. Safe and effective poxvirus vectors-NYVAC and ALVAC. Dev. Biol. Stand. 1994, 82, 65-69.

43. Holzer, G.W.; Falkner, F.G. Construction of a vaccinia virus deficient in the essential DNA repair enzyme uracil DNA glycosylase by a complementing cell line. J. Virol. 1997, 71, 4997-5002.

44. Holzer, G.W.; Remp, G.; Antoine, G.; Pfleiderer, M.; Enzersberger, O.M.; Emsenhuber, W.; Hammerle, T.; Gruber, F.; Urban, C.; Falkner, F.G.; et al. Highly efficient induction of protective immunity by a vaccinia virus vector defective in late gene expression. J. Virol. 1999, 73, 4536-4542.

45. Ober, B.T.; Bruhl, P.; Schmidt, M.; Wieser, V.; Gritschenberger, W.; Coulibaly, S.; Savidis-Dacho, H.; Gerencer, M.; Falkner, F.G. Immunogenicity and safety of defective vaccinia virus lister: Comparison with modified vaccinia virus Ankara. J. Virol. 2002, 76, 7713-7723.

46. Coulibaly, S.; Bruhl, P.; Mayrhofer, J.; Schmid, K.; Gerencer, M.; Falkner, F.G. The nonreplicating smallpox candidate vaccines defective vaccinia lister (DVV-l) and modified vaccinia Ankara (MVA) elicit robust long-term protection. Virology 2005, 341, 91-101.

47. Najera, J.L.; Gomez, C.E.; Domingo-Gil, E.; Gherardi, M.M.; Esteban, M. Cellular and biochemical differences between two attenuated poxvirus vaccine candidates (MVA and NYVAC) and role of the C7L gene. J. Virol. 2006, 80, 6033-6047.

48. Ferrier-Rembert, A.; Drillien, R.; Tournier, J.N.; Garin, D.; Crance, J.M. Short- and long-term immunogenicity and protection induced by non-replicating smallpox vaccine candidates in mice and comparison with the traditional 1st generation vaccine. Vaccine 2008, 26, 1794-1804.

49. Takahashi-Nishimaki, F.; Funahashi, S.; Miki, K.; Hashizume, S.; Sugimoto, M. Regulation of plaque size and host range by a vaccinia virus gene related to complement system proteins. Virology 1991, 181, 158-164.

50. Smith, G.L.; Vanderplasschen, A.; Law, M. The formation and function of extracellular enveloped vaccinia virus. J. Gen. Virol. 2002, 83, 2915-2931.

51. Schmelz, M.; Sodeik, B.; Ericsson, M.; Wolffe, E.J.; Shida, H.; Hiller, G.; Griffiths, G. Assembly of vaccinia virus: The second wrapping cisterna is derived from the trans golgi network. J. Virol. 1994, 68, 130-147.

52. Hollinshead, M.; Rodger, G.; van Eijl, H.; Law, M.; Hollinshead, R.; Vaux, D.J.; Smith, G.L. Vaccinia virus utilizes microtubules for movement to the cell surface. J. Cell Biol. 2001, 154, 389-402.

53. Rietdorf, J.; Ploubidou, A.; Reckmann, I.; Holmstrom, A.; Frischknecht, F.; Zettl, M.; Zimmermann, T.; Way, M. Kinesin-dependent movement on microtubules precedes actin-based motility of vaccinia virus. Nat. Cell Biol. 2001, 3, 992-1000.

54. Ward, B.M.; Moss, B. Visualization of intracellular movement of vaccinia virus virions containing a green fluorescent protein-B5R membrane protein chimera. J. Virol. 2001, 75, 4802-4813.

55. Katz, E.; Ward, B.M.; Weisberg, A.S.; Moss, B. Mutations in the vaccinia virus A33R and B5R envelope proteins that enhance release of extracellular virions and eliminate formation of actin-containing microvilli without preventing tyrosine phosphorylation of the A36R protein. J. Virol. 2003, 77, 12266-12275. 
56. Newsome, T.P.; Scaplehorn, N.; Way, M. Src mediates a switch from microtubule- to actin-based motility of vaccinia virus. Science 2004, 306, 124-129.

57. Payne, L.G.; Kristensson, K. Extracellular release of enveloped vaccinia virus from mouse nasal epithelial cells in vivo. J. Gen. Virol. 1985, 66, 643-646.

58. Galmiche, M.C.; Goenaga, J.; Wittek, R.; Rindisbacher, L. Neutralizing and protective antibodies directed against vaccinia virus envelope antigens. Virology 1999, 254, 71-80.

59. Hooper, J.W.; Custer, D.M.; Thompson, E. Four-gene-combination DNA vaccine protects mice against a lethal vaccinia virus challenge and elicits appropriate antibody responses in nonhuman primates. Virology 2003, 306, 181-195.

60. Pulford, D.J.; Gates, A.; Bridge, S.H.; Robinson, J.H.; Ulaeto, D. Differential efficacy of vaccinia virus envelope proteins administered by DNA immunisation in protection of BALB/c mice from a lethal intranasal poxvirus challenge. Vaccine 2004, 22, 3358-3366.

61. Hooper, J.W.; Thompson, E.; Wilhelmsen, C.; Zimmerman, M.; Ichou, M.A.; Steffen, S.E.; Schmaljohn, C.S.; Schmaljohn, A.L.; Jahrling, P.B. Smallpox DNA vaccine protects nonhuman primates against lethal monkeypox. J. Virol. 2004, 78, 4433-4443.

62. Williamson, J.D.; Reith, R.W.; Jeffrey, L.J.; Arrand, J.R.; Mackett, M. Biological characterization of recombinant vaccinia viruses in mice infected by the respiratory route. J. Gen. Virol. 1990, 71, 2761-2767.

63. Kidokoro, M.S.S.; Ami, Y.; Suzaki, Y.; Nagata, N.; Iwata, N.; Hasegawa, H.; Ogata, M.; Fukushi, H.; Mizutani, T.; Shida, H.; et al. Protective effects of improved smalpox vaccine LC16m8 8 against a lethal monkeypox challenge in cynomolgus monkeys. In Proceedings of the 54th Annual Meeting of the Japanese Society for Virology, Nagoya, Japan, 19-21 November 2006.

64. Hooper, J.W.; Custer, D.M.; Schmaljohn, C.S.; Schmaljohn, A.L. DNA vaccination with vaccinia virus L1R and A33R genes protects mice against a lethal poxvirus challenge. Virology 2000, 266, 329-339.

65. Kaufman, D.R.; Goudsmit, J.; Holterman, L.; Ewald, B.A.; Denholtz, M.; Devoy, C.; Giri, A.; Grandpre, L.E.; Heraud, J.M.; Franchini, G.; et al. Differential antigen requirements for protection against systemic and intranasal vaccinia virus challenges in mice. J. Virol. 2008, 82, 6829-6837.

66. Saijo, M.; Ami, Y.; Suzaki, Y.; Nagata, N.; Iwata, N.; Hasegawa, H.; Ogata, M.; Fukushi, S.; Mizutani, T.; Sata, T.; et al. LC16m8, a highly attenuated vaccinia virus vaccine lacking expression of the membrane protein B5R, protects monkeys from monkeypox. J. Virol. 2006, 80, 5179-5188.

67. Morikawa, S.; Sakiyama, T.; Hasegawa, H.; Saijo, M.; Maeda, A.; Kurane, I.; Maeno, G.; Kimura, J.; Hirama, C.; Yoshida, T.; et al. An attenuated LC16m8 smallpox vaccine: Analysis of full-genome sequence and induction of immune protection. J. Virol. 2005, 79, 11873-11891.

68. Benhnia, M.R.; McCausland, M.M.; Su, H.P.; Singh, K.; Hoffmann, J.; Davies, D.H.; Felgner, P.L.; Head, S.; Sette, A.; Garboczi, D.N.; et al. Redundancy and plasticity of neutralizing antibody responses are cornerstone attributes of the human immune response to the smallpox vaccine. J. Virol. 2008, 82, 3751-3768.

69. Townsend, M.B.; Keckler, M.S.; Patel, N.; Davies, D.H.; Felgner, P.; Damon, I.K.; Karem, K.L. Humoral immunity to smallpox vaccines and monkeypox virus challenge: Proteomic assessment and clinical correlations. J. Virol. 2013, 87, 900-911. 
70. Duke-Cohan, J.S.; Wollenick, K.; Witten, E.A.; Seaman, M.S.; Baden, L.R.; Dolin, R.; Reinherz, E.L. The heterogeneity of human antibody responses to vaccinia virus revealed through use of focused protein arrays. Vaccine 2009, 27, 1154-1165.

71. Moss, B. Vaccinia virus: A tool for research and vaccine development. Science 1991, 252, 1662-1667.

72. Perkus, M.E.; Taylor, J.; Tartaglia, J.; Pincus, S.; Kauffman, E.B.; Tine, J.A.; Paoletti, E. Live attenuated vaccinia and other poxviruses as delivery systems: Public health issues. Ann. NY Acad. Sci. 1995, 754, 222-233.

73. Thongcharoen, P.; Suriyanon, V.; Paris, R.M.; Khamboonruang, C.; de Souza, M.S.; Ratto-Kim, S.; Karnasuta, C.; Polonis, V.R.; Baglyos, L.; Habib, R.E.; et al. A phase 1/2 comparative vaccine trial of the safety and immunogenicity of a CRF01_AE (subtype E) candidate vaccine: ALVAC-HIV (vCP1521) prime with oligomeric gp160 (92TH023/LAI-DID) or bivalent gp120 (CM235/SF2) boost. J. Acquir. Immune Defic. Syndr. 2007, 46, 48-55.

74. Casimiro, D.R.; Wang, F.; Schleif, W.A.; Liang, X.; Zhang, Z.Q.; Tobery, T.W.; Davies, M.E.; McDermott, A.B.; O'Connor, D.H.; Fridman, A.; et al. Attenuation of simian immunodeficiency virus SIVmac239 infection by prophylactic immunization with DNA and recombinant adenoviral vaccine vectors expressing Gag. J. Virol. 2005, 79, 15547-15555.

75. Vogel, T.U.; Reynolds, M.R.; Fuller, D.H.; Vielhuber, K.; Shipley, T.; Fuller, J.T.; Kunstman, K.J.; Sutter, G.; Marthas, M.L.; Erfle, V.; et al. Multispecific vaccine-induced mucosal cytotoxic T lymphocytes reduce acute-phase viral replication but fail in long-term control of simian immunodeficiency virus SIVmac239. J. Virol. 2003, 77, 13348-13360.

76. Cox, K.S.; Clair, J.H.; Prokop, M.T.; Sykes, K.J.; Dubey, S.A.; Shiver, J.W.; Robertson, M.N.; Casimiro, D.R. DNA gag/adenovirus type 5 (Ad5) gag and Ad5 gag/Ad5 gag vaccines induce distinct T-cell response profiles. J. Virol. 2008, 82, 8161-8171.

77. Goonetilleke, N.; Moore, S.; Dally, L.; Winstone, N.; Cebere, I.; Mahmoud, A.; Pinheiro, S.; Gillespie, G.; Brown, D.; Loach, V.; et al. Induction of multifunctional human immunodeficiency virus type 1 (HIV-1)-specific $\mathrm{T}$ cells capable of proliferation in healthy subjects by using a prime-boost regimen of DNA- and modified vaccinia virus ankara-vectored vaccines expressing HIV-1 gag coupled to CD8 ${ }^{+}$T-cell epitopes. J. Virol. 2006, 80, 4717-4728.

78. Harari, A.; Bart, P.A.; Stohr, W.; Tapia, G.; Garcia, M.; Medjitna-Rais, E.; Burnet, S.; Cellerai, C.; Erlwein, O.; Barber, T.; et al. An HIV-1 clade C DNA prime, NYVAC boost vaccine regimen induces reliable, polyfunctional, and long-lasting T cell responses. J. Exp. Med. 2008, 205, 63-77.

79. Tameris, M.D.; Hatherill, M.; Landry, B.S.; Scriba, T.J.; Snowden, M.A.; Lockhart, S.; Shea, J.E.; McClain, J.B.; Hussey, G.D.; Hanekom, W.A.; et al. Safety and efficacy of MVA85A, a new tuberculosis vaccine, in infants previously vaccinated with BCG: A randomised, placebo-controlled phase 2b trial. Lancet 2013, 381, 1021-1028.

80. Walker, B.D.; Burton, D.R. Toward an AIDS vaccine. Science 2008, 320, 760-764.

81. Kitabatake, M.; Inoue, S.; Yasui, F.; Yokochi, S.; Arai, M.; Morita, K.; Shida, H.; Kidokoro, M.; Murai, F.; Le, M.Q.; et al. SARS-CoV spike protein-expressing recombinant vaccinia virus efficiently induces neutralizing antibodies in rabbits pre-immunized with vaccinia virus. Vaccine 2007, 25, 630-637.

82. Viner, K.M.; Girgis, N.; Kwak, H.; Isaacs, S.N. B5-deficient vaccinia virus as a vaccine vector for the expression of a foreign antigen in vaccinia immune animals. Virology 2007, 361, 356-363. 
83. Jin, N.Y.; Funahashi, S.; Shida, H. Constructions of vaccinia virus A-type inclusion body protein, tandemly repeated mutant $7.5 \mathrm{kDa}$ protein, and hemagglutinin gene promoters support high levels of expression. Arch. Virol. 1994, 138, 315-330.

84. Kidokoro, M.; Aoki, A.; Horiuchi, K.; Shida, H. Large-scale preparation of biologically active measles virus haemagglutinin expressed by attenuated vaccinia virus vectors. Microbes Infect. 2002, 4, 1035-1044.

85. Funahashi, S.; Sato, T.; Shida, H. Cloning and characterization of the gene encoding the major protein of the A-type inclusion body of cowpox virus. J. Gen. Virol. 1988, 69, 35-47.

86. Suzuki, H.; Kidokoro, M.; Fofana, I.B.; Ohashi, T.; Okamura, T.; Matsuo, K.; Yamamoto, N.; Shida, H. Immunogenicity of newly constructed attenuated vaccinia strain LC16m8delta that expresses SIV gag protein. Vaccine 2009, 27, 966-971.

87. Kiepiela, P.; Ngumbela, K.; Thobakgale, C.; Ramduth, D.; Honeyborne, I.; Moodley, E.; Reddy, S.; de Pierres, C.; Mncube, Z.; Mkhwanazi, N.; et al. CD8 ${ }^{+}$T-cell responses to different HIV proteins have discordant associations with viral load. Nat. Med. 2007, 13, 46-53.

88. Matano, T.; Kobayashi, M.; Igarashi, H.; Takeda, A.; Nakamura, H.; Kano, M.; Sugimoto, C.; Mori, K.; Iida, A.; Hirata, T.; et al. Cytotoxic T lymphocyte-based control of simian immunodeficiency virus replication in a preclinical AIDS vaccine trial. J. Exp. Med. 2004, 199, 1709-1718.

89. Okamura, T.; Someya, K.; Matsuo, K.; Hasegawa, A.; Yamamoto, N.; Honda, M. Recombinant vaccinia Dis expressing simian immunodeficiency virus gag and pol in mammalian cells induces efficient cellular immunity as a safe immunodeficiency virus vaccine candidate. Microbiol. Immunol. 2006, 50, 989-1000.

90. Mackett, M.; Smith, G.L.; Moss, B. General method for production and selection of infectious vaccinia virus recombinants expressing foreign genes. J. Virol. 1984, 49, 857-864.

91. Hansen, S.G.; Vieville, C.; Whizin, N.; Coyne-Johnson, L.; Siess, D.C.; Drummond, D.D.; Legasse, A.W.; Axthelm, M.K.; Oswald, K.; Trubey, C.M.; et al. Effector memory T cell responses are associated with protection of rhesus monkeys from mucosal simian immunodeficiency virus challenge. Nat. Med. 2009, 15, 293-299.

92. Hansen, S.G.; Ford, J.C.; Lewis, M.S.; Ventura, A.B.; Hughes, C.M.; Coyne-Johnson, L.; Whizin, N.; Oswald, K.; Shoemaker, R.; Swanson, T.; et al. Profound early control of highly pathogenic SIV by an effector memory T-cell vaccine. Nature 2011, 473, 523-527.

93. Sato, H.; Jing, C.; Isshiki, M.; Matsuo, K.; Kidokoro, M.; Takamura, S.; Zhang, X.; Ohashi, T.; Shida, H. Immunogenicity and safety of the vaccinia virus LC16m8delta vector expressing SIV Gag under a strong or moderate promoter in a recombinant BCG prime-recombinant vaccinia virus boost protocol. Vaccine 2013, 31, 3549-3557.

94. Goepfert, P.A.; Elizaga, M.L.; Seaton, K.; Tomaras, G.D.; Montefiori, D.C.; Sato, A.; Hural, J.; Derosa, S.C.; Kalams, S.A.; McElrath, M.J.; et al. Specificity and 6-month durability of immune responses induced by DNA and recombinant modified vaccinia Ankara vaccines expressing HIV-1 virus-like particles. J. Infect. Dis. 2014, 210, 99-110. 
95. Zhang, X.; Sobue, T.; Isshiki, M.; Makino, S.; Inoue, M.; Kato, K.; Shioda, T.; Ohashi, T.; Sato, H.; Komano, J.; et al. Elicitation of both anti HIV-1 Env humoral and cellular immunities by replicating vaccinia prime sendai virus boost regimen and boosting by CD40Lm. PLoS One 2012, 7, e51633.

(C) 2014 by the authors; licensee MDPI, Basel, Switzerland. This article is an open access article distributed under the terms and conditions of the Creative Commons Attribution license (http://creativecommons.org/licenses/by/4.0/). 